Original Research Paper

\title{
Prevalence of Asthma Bronchiale in the Czech Republic and its Economic Burden
}

\author{
${ }^{1}$ Richter Josef, ${ }^{1}$ Kral Vlastimil, ${ }^{1}$ Rajnohova Dobiasova Lucie, \\ ${ }^{2}$ Svozil Vladimir, ${ }^{3}$ Pohunek Petr and ${ }^{4}$ Vetvicka Vaclav \\ ${ }^{1}$ Regional Institute of Public Health, Ústí nad Labem, Czech Republic \\ ${ }^{2}$ Sanatorium Edel, Zlaté Hory, Czech Republic \\ ${ }^{3}$ Department of Pediatrics, 2 nd Faculty of Medicine, Charles University in Prague, Czech Republic \\ ${ }^{4}$ Department of Pathology, School of Medicine, University of Louisville, Louisville, KY, USA
}

\author{
Article history \\ Received: 13-06-2016 \\ Revised: 15-08-2016 \\ Accepted: 18-08-2016 \\ Corresponding Author: \\ Vaclav Vetvicka \\ Department of Pathology, \\ University of Louisville, $511 \mathrm{~S}$. \\ Floyd, Louisville, KY 40292, \\ USA \\ Email: Vaclav.vetvicka@louisville.edu
}

\begin{abstract}
Asthma Bronchiale (AB) is a chronic inflammatory disorder of the airways currently affecting around $350,000,000$ patients in the world. A steady increase in prevalence of this disease was the incentive for our study of the prevalence of $\mathrm{AB}$ in the Czech Republic. Special attention was focused on possible differential regional incidence. We found that prevalence of this disease in an age group $0-14$ years is $5.21 \%$, in age group of $15-19$ is $11.5 \%$. In the $2000-2013$ period, we observed a $268 \%$ increase in the 0-14 group and $685 \%$ increase in the $15-19$ group. Using published materials, we used medical costs values from other European countries, which are in range of 600 to 3,200 dollars to calculate the finacial burden in the Czech Republic. When we used a conservative estimate of $\$ 1,200$, the total costs of $A B$ treatment in the $0-14$ years group is $\$ 66,475,200$ per year. When compared with the year 2000, the increase in financial costs is more than $\$ 50,000,000$, with the anticipated increase of $\$ 30,000,000$ every single year. These findings indicate that there is a necessity to increase interest in primary prevention and early diagnosis of this disease.
\end{abstract}

Keywords: Asthma, Asthma Bronchiale, Economic Impact, Population, Costs

\section{Introduction}

Asthma Bronchiale (AB) is a chronic inflammatory disorder of the airways currently affecting app. 350 million patients worldwide (Aldubi et al., 2015; Bahadori et al., 2009; Busaidi-Al et al., 2013; D'Amato et al., 2015; Litonjua and Weiss, 2007). Prevalence of this disease is steadily increasing, particularly in industrial countries and in some European countries is already higher than $10 \%$ of infantile population (Litonjua and Weiss, 2007; Bedouch et al., 2012; Doz et al., 2013; Kasak, 2005; Negro et al., 2007). This trend is very similar in the Czech Republic, particularly in the infantile population (Kasak, 2005; Petru, 2008; Pohunek and Slamova, 2009; Pohunek et al., 2009). Despite the fact that in recent years there is considerable attention focused on diagnostic of all allergic diseases including $\mathrm{AB}$, a full and precise diagnosis is still often unsatisfactory, with subsequent problems starting treatment at the earliest start of this disease (Bedouch et al., 2012; Doz et al., 2013; Pakhale et al., 2011; Petru, 2008; Pohunek et al., 2009; Zhang et al., 2015). Problems in evidence of AB, leading to disproportional evidence of $\mathrm{AB}$ in individual regions, are also significant (Gudelj et al., 2012; Hansen et al., 2012). An exact and early diagnosis can significantly reduce progression of clinical manifestation of $\mathrm{AB}$ and thus strongly lower financial burden (Bahadori et al., 2009; Litonjua and Weiss, 2007; Edwards et al., 2011; Doz et al., 2013; Pohunek et al., 2009).

Prevalence of $\mathrm{AB}$ is constantly increasing, even if this trend is different in individual countries (Accordini et al., 2013; Bahadori et al., 2009; Litonjua and Weiss, 2007; D'Amato et al., 2015; Doz et al., 2013; Gudelj et al., 2012; Kim et al., 2013; Wong et al., 2013; Zalewska et al., 2013). Numerous inductors are considered to be responsible for an increase in $\mathrm{AB}$ prevalence, among others it is urbanization and environmental pollution, but also more precise diagnostic and registration (Anderson et al., 2012; Bonds and Midoro-Horiuti, 2013; Daghri-Al et al., 2013; D'Amato et al., 2015; Lamnisos et al., 2013; Patel et al., 2012). The estimated increase in AB prevelance for the year 2025 is at least 30\% (Bahadori et al., 2009; Sadatsafavi et al., 2010; To et al., 2013; Wong et al., 2013). 
This trend started serious discussion in many countries concerned with rising economic burden, necessary for the care of patients. These economic problems include both direct and indirect costs. The ever increasing trend of $\mathrm{AB}$ occurrence is the reason of this review.

\section{Materials and Methods}

\section{Resources}

Data for evaluation of $\mathrm{AB}$ prevalence in individual European countries were obtained by a systematic search of following databases: PubMed NL, HomePubMed-CBI, Europe-PubMed Central, Biomedical Search, Free Medical Journals, Amedeo Services and NIH-National Library of Medicine. We used data from European countries for a 2004-2011 interval and calculated average prevelance values. For the Czech Republic, we used data from Czech Health Statistics Yearbook published by the Ministry of Health for years 2006-2013 (UZIS, 2013).

For calculation of costs of $\mathrm{AB}$ treatment we used primarily direct costs. Indirect costs and additional costs such as effects on social and economical situation of the entire family and work or school absence were not used due to the highly conflicting data published in individual countries (Pasquale et al., 2012; Sadatsafavi et al., 2010; Tan et al., 2009; Zehraeus et al., 2010).

\section{Results}

\section{Epidemiology of Asthma Bronchiale}

In general, literature describes a steady and significant increase in AB prevalence (D'Amato et al., 2015; Doz et al., 2013; Kasak, 2005; Litonjua and Weiss, 2007). In Asia, the prevalence is around 2-4\%, in industrial countries (such as Canada, Australia, Ireland, Great Britain, Sweden and New Zealand) reached 15$20 \%$ (D'Amato et al., 2015). This information led us to analyze the situation in Europe. We based our investigation on published data from 2006-2013 period and we calculated average values for each individual country. Appearance of AB in Europe is shown in Fig. 1. It clearly shows higher appearance in the industrial countries of Western Europe and Scandinavia. On the other hand, Eastern Europe shows significantly lower levels. In the Czech Republic, the situation was significantly different among individual regions (Fig. 2). The highest appearance of $\mathrm{AB}$ was found in eastern regions of the republic, where $\mathrm{AB}$ can be found more than twice as often as in the rest of country.

Comparing data from 2000 and 2013 we can observe a clear and statistically significant increase of AB. With respect to possible risk factors such as geographical location, effects of irradiation, urbanization, environmental pollution, smoking or forestation shown in Table 1 (D'Amato et al., 2015; Toskala and Kennedy, 2015), no significant differences in AB appearance were found.

\section{Economical Impact}

The economic impact of $\mathrm{AB}$ treatment has been the subject of numerous studies (Accordini et al., 2013; Bahadori et al., 2009; Bedouch et al., 2012; Doz et al., 2013; Kirsch et al., 2013; Meer et al., 2011; Negro et al., 2007; Pakhale et al., 2011; Rodriguez et al., 2011; Tan et al., 2009; Zehraeus et al., 2010). Direct costs include cost of ambulatory care, hospitalization, drugs, diagnostics, research and education. Indirect costs include loss of employment or school attendance, loss in productivity, family costs and other financial problems (Accordini et al., 2013; Bahadori et al., 2009; Busaidi-Al et al., 2013; D'Amato et al., 2015; Doz et al., 2013; Meer et al., 2011; Sadatsafavi et al., 2010). Calculation of either direct or indirect costs in the Czech Republic is rather difficult. Costs of drugs and diagnostics are similar to other countries; total costs of $\mathrm{AB}$ treatment are shown in Table 2. It is important to note that the calculation of costs is substantially different among individual countries. Some Arabic countries and South Korea reported \$5,600/year as a maximal costs. Indirect costs described in numerous studies vary from 15 to $67 \%$ of total costs (Honkoop et al., 2011; Pakhale et al., 2011; Tan et al., 2009; Zehraeus et al., 2010). Aproximate costs of $\mathrm{AB}$ treatment in the Czech Republic was calculated based on the cost of drugs, diagnostics and screening of patients in our hospital.

In 2013, Czech Republic registered 85,644 asthmatics in 0-14 year age group. At the same time, this population of children represented a total of 1,470,952 individuals; therefore the segment of $\mathrm{AB}$ patients in this group is $5.21 \%$. Total cost of a year of treatment was $\$ 102,772,800$. Our hospital showed 650 patients with costs ranging from $\$ 300$ to $\$ 3,440$ with an average cost of $\$ 1,200$. Using the same calculation, the cost of treating one patient in 2001 was $\$ 44,000,400$.

In the 15-19 year group we registered 13,233 patients in 2001 , in the year 2013 it was already 55,396 patients. The costs rose from $\$ 15,900,000$ to $\$ 66,500,000$. As can be seen from the growing trend, the significant growth of patients in both age groups is followed by similarly significant increase in costs. In addition, there are no doubts that this trend will continue. An estimate for 2020 suggests that without changes in treatment and/or registration, the costs will increase 30 to $50 \%$. All this strongly underlines the need to come up with primary preventive measurements and with earlier and more accurate clinical and laboratory diagnostic and earlier treatment of AB. 


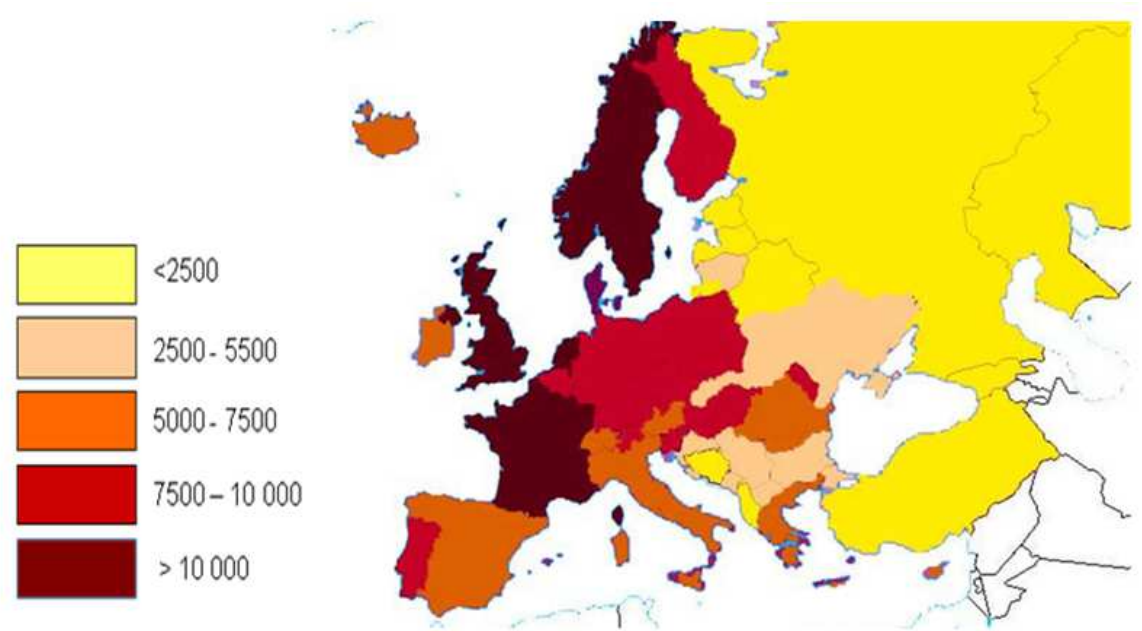

Fig. 1. Asthmabronchiale prevalence in Europiancoutries (2008-2012). Asthma bronchiale cases per 100000 inhabitants
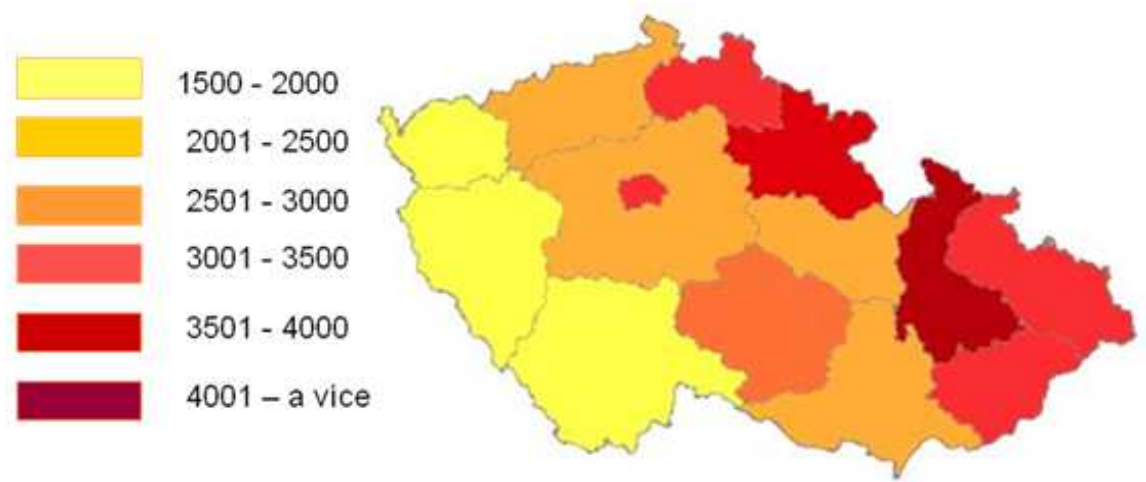

Fig. 2. Asthmabronchiale in regions of the Czech Republic (2013). Asthma bronchiale cases per 100000 inhabitants

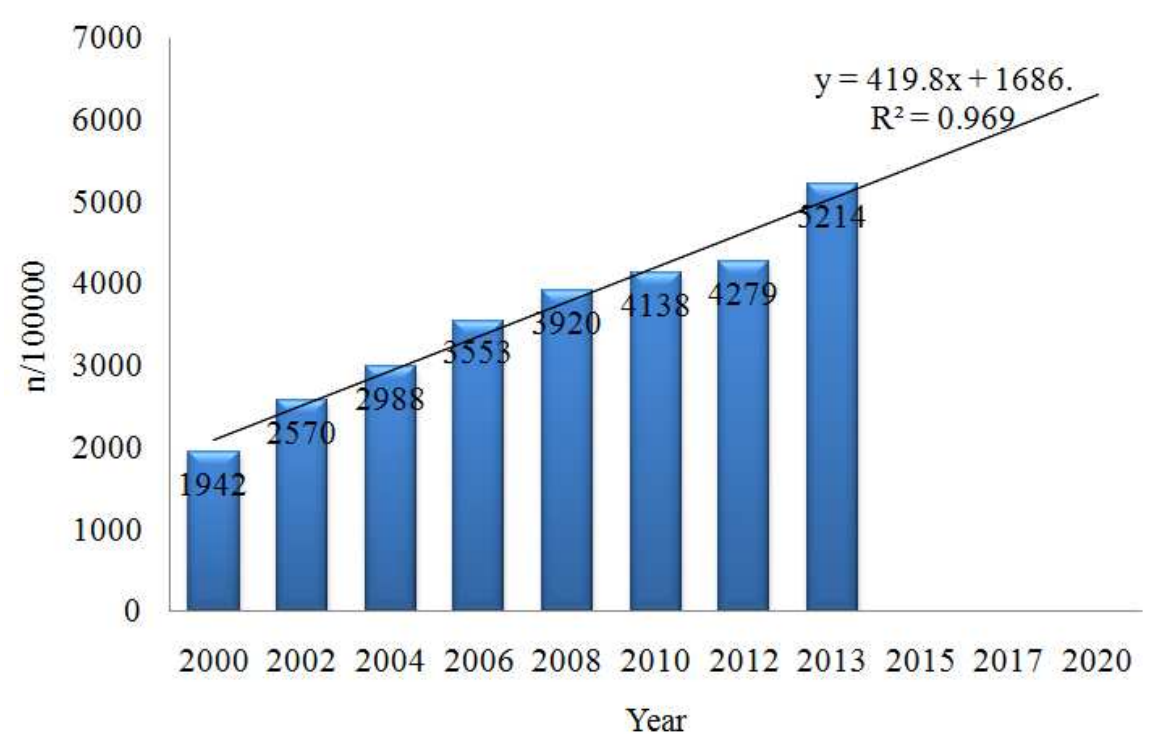

Fig. 3. Asthma bronchiale prevalence in children of the Czech republic-(Age years 0-14)-Followed up patients per 100000 inhabitants 


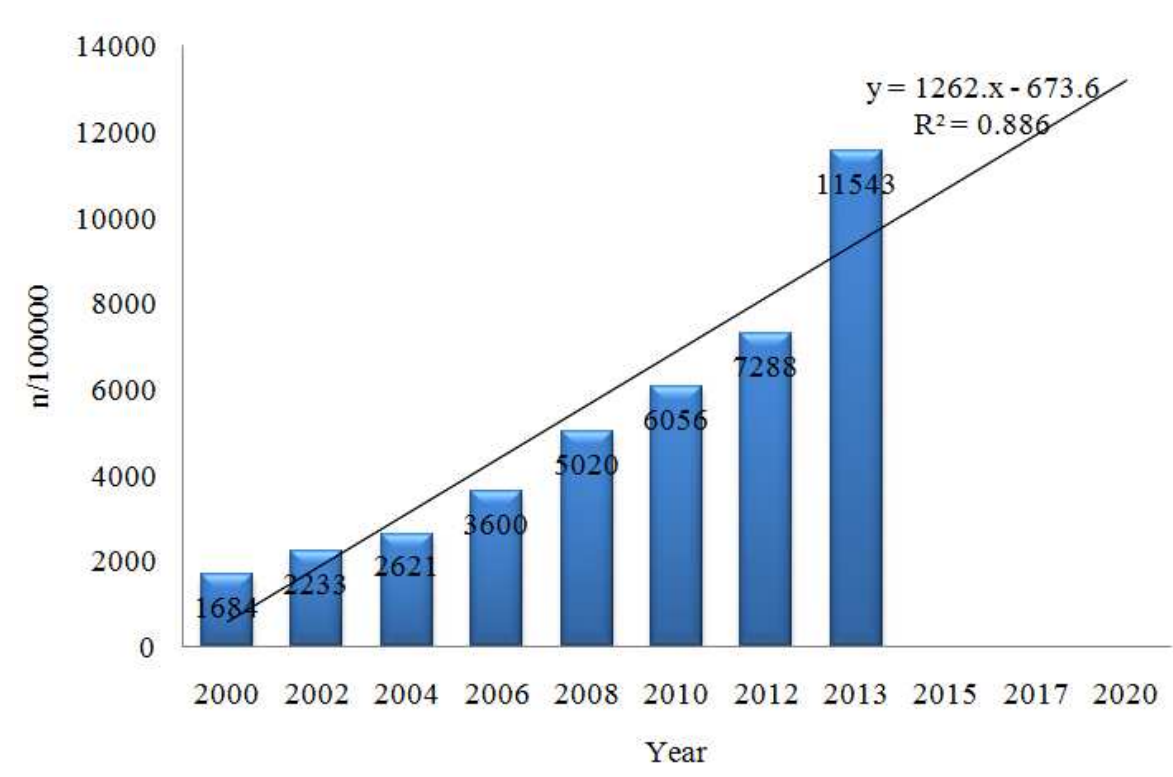

Fig. 4. Asthma bronchiale prevalence in children of the Czech republic-(Age years15-19)-Followed up patients per 100000 inhabitants

Table 1. Risk factors asthma bronchiale induction

\begin{tabular}{|c|c|}
\hline Risk factor & Reference \\
\hline Allergy & $\begin{array}{l}\text { Aldubi et al. (2015; Anderson et al., 2012; Bahadori et al., 2009; Bedouch et al., 2012; } \\
\text { Bonds and Midoro-Horiuti, 2013; Gudelj et al., 2012; Patel et al., 2012) }\end{array}$ \\
\hline Genetics & $\begin{array}{l}\text { Karmaus et al. (2013; Kim et al., 2013; Kirsch et al., 2013; Pasquale et al., 2012; } \\
\text { Patel et al., 2012; Petru, 2008; Rodriguez et al., 2011) }\end{array}$ \\
\hline Sex & Anderson et al. (2012; Bedouch et al., 2012; Daghri-Al et al., 2013; Patel et al., 2012) \\
\hline Locality/UV/radiation & $\begin{array}{l}\text { Aldubi et al. (2015; Daghri-Al et al., 2013; D'Amato et al., 2015; Doz et al., 2013; } \\
\text { Edwards et al., 2011; Karmaus et al., 2013; Kirsch et al., 2013; To et al., 2012; } \\
\text { Wong et al., 2013; Zalewska et al., 2013) }\end{array}$ \\
\hline Locality of residence & $\begin{array}{l}\text { Krstic (2011; Pasquale et al., 2012; Pittman et al., 2012; Rodriguez et al., 2011; } \\
\text { To et al., 2012) }\end{array}$ \\
\hline Urbanization & Rodriguez et al. (2011; Wong et al., 2013) \\
\hline Air pollution & $\begin{array}{l}\text { Anderson et al. (2012; Bahadori et al., 2009; Daghri-Al et al., 2013; Edwards et al., } \\
\text { 2011; Karmaus et al., 2013; Patel et al., 2012; Petru, 2008; Stoner et al., 2013; } \\
\text { Toru et al., 2015) }\end{array}$ \\
\hline Diesel fuel & Busaidi-Al et al. (2013; Subbarao et al., 2009) \\
\hline PCB-PAH & Busaidi-Al et al. (2013; Subbarao et al., 2009) \\
\hline Estrogens & Bonds and Midoro-Horiuti (2013) \\
\hline Pets & Subbarao et al. (2009; Wong et al., 2013) \\
\hline Socioeconomical influence & $\begin{array}{l}\text { Bahadori et al. (2009; Honkoop et al., 2011; Kim et al., 2012; Kirsch et al., 2013; } \\
\text { Pittman et al., 2012; Rodriguez et al., 2011; Subbarao et al., 2009) }\end{array}$ \\
\hline Smoking & $\begin{array}{l}\text { Doz et al. (2013; Gudelj et al., 2012; Karmaus et al., 2013; Lamnisos et al., 2013; } \\
\text { Patel et al., 2012; Pittman et al., 2012; Subbarao et al., 2009; To et al., 2012) }\end{array}$ \\
\hline Passive smoking & $\begin{array}{l}\text { Gudelj et al. (2012; Kim et al., 2012; Lamnisos et al., 2013; Patel et al., 2012; } \\
\text { Pittman et al., 2012; Pohunek et al., 1999; Stoner et al., 2013; Subbarao et al., 2009) }\end{array}$ \\
\hline Nutrition & Daghri-Al et al. (2013; Patel et al., 2012; Rodriguez et al., 2011; Subbarao et al.,2009) \\
\hline Vitamin D & Aldubi et al. (2015; Krstic, 2011; Litonjua and Weiss, 2007) \\
\hline Obesity & Negro et al. (2007; Patel et al., 2012) \\
\hline Helicobacter pylori & Karimi et al. (2013) \\
\hline Endotoxins & Subbarao et al. (2009; Wong et al., 2013) \\
\hline Specific IgE & Song et al. (2013) \\
\hline Exposure to allergens & Patel et al., 2012; Pittman et al., 2012; Subbarao et al., 2009) \\
\hline Exposure to molds & $\begin{array}{l}\text { Patel et al. (2012; Petru, 2008; Pohunek et al., 1999; Pohunek and Slamova, 1999; } \\
\text { Toru et al., 2015; Pringle, 2013) }\end{array}$ \\
\hline Stress & Pittman et al. (2012; Tan et al., 2009) \\
\hline ATB therapy & Patel et al. (2012; Stoner et al., 2013) \\
\hline
\end{tabular}


Table 2. Cost of treating asthma bronchiale

\begin{tabular}{|c|c|c|c|}
\hline Country & Direct costs $(\$)$ & Indirect costs $(\%)$ & Reference \\
\hline \multirow[t]{4}{*}{ Italy } & 1,396 & 62.5 & Accordini et al. (2013) \\
\hline & 1,186 & 50 & Anderson et al. (2012) \\
\hline & 1,432 & 15 & Pakhale et al. (2011) \\
\hline & 800 & - & Zehraeus et al. (2010) \\
\hline Switzerland & 2,200 & - & Bedouch et al. (2012) \\
\hline \multirow[t]{2}{*}{ Spain } & 3,200 & - & Bedouch et al. (2012) \\
\hline & 1,400 & - & Edwards et al. (2011) \\
\hline \multirow[t]{2}{*}{ France } & 1,300 & - & Edwards et al. (2011) \\
\hline & 750 & - & Anderson et al. (2012) \\
\hline Germany & 1,500 & - & Krstic (2011) \\
\hline Denmark & 1,000 & 67 & Bedouch et al. (2012) \\
\hline Turkey & 1,400 & 20 & Anderson et al. (2012) \\
\hline Sweden & 640 & - & Anderson et al. (2012) \\
\hline Netherlands & 2,100 & 50 & Negro et al. (2007) \\
\hline USA & 1,400 & - & Tan et al. (2009) \\
\hline Canada & 400 & & $\begin{array}{l}\text { Pasquale et al. (2012; } \\
\text { Sadatsafavi et al., 2010) }\end{array}$ \\
\hline South Korea & $1,200-5,600$ & - & Kim et al. (2012) \\
\hline
\end{tabular}

\section{Discussion}

Asthma bronchiale represents a major health issue in industrialized countries. It is an insufficiently defined syndrome characterized by several phenotypes most probably with different etiology (Gudelj et al., 2012). The biggest problem is the fact that we still do not know the optimal standard for exact diagnosis and its relevant evaluation in epidemiological studies, so exact registration is difficult (Gudelj et al., 2012). Therefore, resulting value of $\mathrm{AB}$ registration differs based on methods used. The error in registered occurrence of $A B$ can reach up to $20 \%$. In industrialized countries, the costs of treatment $\mathrm{AB}$ reach $1-2 \%$ of total medical costs (Karmaus et al., 2013). However, is some countries can reach even up to $55 \%$ (Weissflog et al., 2001). Canadian study found $20.5 \%$ of const is attributable to inpatient care, $47.8 \%$ to outpatient care and $31.5 \%$ to medication (Sadatsafavi et al., 2016). In the United States, the asthma epidemics are also on the rise, from 3\% in 1970 to $7.8 \%$ in 2008 . The total costs per year are estimated to be $\$ 56$ billions (Loftus and Wise, 2015).

To fully evaluate the cost of treatment in the Czech Republic is difficult. Direct costs are similar to other countries, but indirect costs influencing negative economical effects on individual, family and the whole society is impossible to calculate. Similarly, it is not possible to calculate costs of $\mathrm{AB}$ co-morbidity, as they are often treated by different departments or clinics by physicians trained in different specialties and the costs are not correlated with original diagnosis. It might be possible to gain complex information from the evidence of health care insurance, which in the Czech Republic covers almost the entire population. So far, we do not know any simple specific marker confirming $\mathrm{AB}$ diagnosis in all age groups. The basis of $\mathrm{AB}$ diagnosis is to focus attention on the detailed differential diagnosis of this disease (Negro et al., 2007). The main reasons for insufficient diagnosis of $\mathrm{AB}$ are probably general underestimation of occurrence of this disease, which is much higher than generally expected and with a steady increasing trend (Patel et al., 2012). An increase in AB prevalence for the next two decades is expected to reach $25 \%$. The same trend can be expected in the Czech Republic, as we found more than a $10 \%$ increase in the 2000-2013 period (Fig. 3 and 4).

The number of factors involved in induction of $\mathrm{AB}$ is high and is constantly increasing with new studies. We evaluated many of these factors, but no significant correlation in their appearance with respect to geographical localization. Data of prevalence of $\mathrm{AB}$ in individual location and regions are most probably influenced with methods of registration of $\mathrm{AB}$, particularly in a small location within main region of pediatricians. Evidence of the use of drugs for $\mathrm{AB}$ treatment might serve as a solid control mechanism for verification of $\mathrm{AB}$ diagnosis. Some studies evaluated registration and validation of diagnosis and found $89 \%$ sensitivity and $72 \%$ specificity of accurate diagnosis in the children population (Sadatsafavi et al., 2010; Subbarao et al., 2009). Regional prevalence of $\mathrm{AB}$ was also studied in Poland. This study showed differences in occurrence of $\mathrm{AB}$ among regions (Zalewska et al., 2013). Our current study has similar conclusions. A more direct analysis of importance of these findings is currently under way.

Total costs for $\mathrm{AB}$ treatment should be evaluated separately, as our estimates have only partial validity. We used minimal costs published in studies from European countries and used most of all costs of drugs and laboratory diagnostics, where there are minimal differences between European countries. The values of other factors can significantly differ, mostly based on 
level of economical advancement and on different level of income among countries.

\section{Conclusion}

Ever increasing prevalence of $\mathrm{AB}$ will require increased attention not only in prevention, but also in diagnostics. There is strong need for early recognition of asthma and for adequate treatment. The failure in solving this problem will be associated with significant and to some extent even potentially crippling, the economic burden of health system.

\section{Acknowledgement}

Authors wish to acknowledge excellent technical help of Ms. Tassie Deppert.

\section{Funding Information} Health.

This study was funded by Regional Institute of Public

\section{Author's Contributions}

All authors equally contributed to this study.

\section{Ethics}

This article is original and contains unpublished material. The corresponding author confirms that all of the other authors have read and approved the manuscript and that no ethical issues were involved.

\section{References}

Accordini, S., A.G. Corsico, B. Braggion, M.W. Gerbase and D. Gislason et al., 2013. The cost of persistent asthma in Europe: An international populationbased study in adults. Int. Arch. Allergy Immunol., 160: 93-101. DOI: $10.1159 / 000338998$

Aldubi, H.A., E.M. Alissa, H.Z. Kamfar, O. Gaber and Z.M. Marzouki et al., 2015. Bronchial asthma and Hypovitaminosis D in Saudi children. Asia Pac Allergy, 5: 10-113.

DOI: 10.5415/apallergy.2015.5.2.103

Anderson, H.R., B.K. Butland, A. Donkelaar, M. Brauer and D.P. Strachan et al., 2012. Satellite-based estimates of ambient air pollution and global variations in childhood asthma prevalence. Environ. Health Perspect., 120: 1333-1339.

DOI: $10.1289 /$ ehp. 1104724

Bahadori, K., M.M. Doyle-Waters and C. Marra, 2009. Economic burden of asthma: A systematic review. BMC Pulm. Med., 9: 24-24.

DOI: $10.1186 / 1471-2466-9-24$
Bedouch, P., C.A. Marra and J.M. FitzGerald, L.D. Lynd and M. Sadatsafavi et al., 2012. Trends in asthmarelated direct medical costs from 2002 to 2007 in British Columbia, Canada: A population based-cohort study. Plos One. DOI: 10.1371/journal.pone.0050949

Bonds, R.S. and T. Midoro-Horiuti, 2013. Estrogen effects in allergy and asthma. Curr. Opin. Allergy Clin. Immunol., 13: 92-99. DOI: 10.1097/ACI.0b013e32835a6dd6

Busaidi-Al., N.H., Z. Habibullah and J.B. Soriano, 2013. The asthma cost in Oman. Sultan Qaboos Univ., Med. J., 13: 218-222. PMID: 23862026

D'Amato, G., S.T. Holgate, R. Pawankar, D.K. Ledford and L. Cecchi et al., 2015. Meteorological conditions, climate change, new emerging factors, and asthma and related allergic disorders. A statement of the World Allergy Organization. WAO J., 8: 25-25. DOI: 10.1186/s40413-015-0073-0

Daghri-Al, N.M., M.S. Alokail and S.H. Abd-Alrahman, 2013. Polycyclic aromatic hydrocarbon exposure and pediatric asthma in children: A case-control study. Environ. Health, 12: 1-7.

DOI: $10.1186 / 1476-069 X-12-1$

Doz, M., C. Chouaid and L. Com-Ruelle, 2013. The association between asthma control, health care cost and quality of life in France and Spain. BMC Pulm. Med., 13: 1-15. DOI: 10.1186/1471-2466-13-15

Edwards, R.T., R.D. Neal, P. Linck, L. Mullock and N. Nelhans et al., 2011. Enhancing ventilation in homes of children with asthma: Cost-effectiveness study alongside randomised controlled trial. Brit. J. Gen Pract., 61: e733-741. DOI: $10.3399 /$ bjgp11X606645

Gudelj, I., K.I. Mrkic, H. Munivrana Škvorc, K. Miše and $\breve{Z}$. Vrbica et al., 2012. Intraregional differences in asthma prevalence and risk factors for asthma among adolescents in Split-Dalmatia County, Croatia. Med. Sci. Monit., 18: 43-50. DOI: 10.12659/MSM.882609

Hansen, S., M. Strom, E. Maslova, E.L. Mortensen and C. Granström et al., 2012. A comparison of three methods to measure asthma in epidemiologic studies: Results from the Danish national birth cohort. Plos One. DOI: 10.1371/journal.pone.0036328

Honkoop, P.J., R.J. Loymans, E.H. Termeer, J.B. Snoeck-Stroband and M.J. Bakker et al., 2011. Asthma Control Cost-Utility Randomized Trial Evaluation (ACCURATE): The goals of asthma treatment. BMC Pulm. Med., 11: 1-53. DOI: 10.1186/1471-2466-11-53

Karimi, A., K. Fakhimi-Derakhshan and F. Imanzadeh, 2013. Helicobacter pylori infection and pediatric asthma. Iran. J. Microbiol., 5: 132-135. 
Karmaus, W., A.H. Ziyab, T. Everson and J.W. Holloway, 2013. Epigenetic mechanisms and models in the origins of asthma. Curr. Opin. Allergy Clin. Immunol., 13: 38-44.

DOI: 10.1097/ACI.0b013e32835ad0e7

Kasak, V., 2005. Aktuální klinická doporučení pro léčbu astmatu. Int. Med. Praxi, 4: 178-181.

Kim, H.Y., E.B. Kwon, J.H. Baek, Y.H. Shin and H.Y. Yum et al., 2013. Prevalence and comorbidity of allergic diseases in preschool children. Korean J. Pediatr., 56: 338-342. DOI: $10.3345 / \mathrm{kjp} .2013 .56 .8 .338$

Kim, S.H., T.W. Kim, J.W. Kwon, J.W. Kwon and H.R. Kang et al., 2012. Economic costs for adult asthmatics according to severity and control status in Korean tertiary hospitals. J. Asthma, 49: 303-309. DOI: $10.3109 / 02770903.2011 .641046$

Kirsch, F., C.M. Teuner, P. Menn and R. Leidl, 2013. Costs of illness for asthma and COPD in adults in Germany. Gesundheitswesen, 75: 413-423. PMID: 23553190

Krstic, G., 2011. Asthma prevalence associated with geographical latitude and regional insolation in the United States of America and Australia. Plos ONE. PMID: 21494627

Lamnisos, D., M. Moustaki and O. Kolokotroni, 2013. Prevalence of asthma and allergies in children from the Greek-Cypriot and Turkish-Cypriot communities in Cyprus: A bi-communal crosssectional study. BMC Public Health, 13: 585-599. DOI: $10.1186 / 1471-2458-13-585$

Litonjua, A.A. and S.T. Weiss, 2007. Is vitamin D deficiency to blame for the asthma epidemic? J. Allergy Clin. Immunol., 120: 1031-1035. DOI: 10.1016/j.jaci.2007.08.028

Loftus, P.A. and S.K. Wise, 2015. Epidemiology and economic burden of asthma. Int. Forum Allergy Rhinology, 5: S7-S10. DOI: 10.1002/alr.21547

Meer, V., W.B. Hout, M.J. Bakker, K.F. Rabe and P.J. Sterk et al., 2011. Cost-effectiveness of internetbased self-management compared with usual care in asthma. Plos One, 6: e27108-e27108.

DOI: 10.1371/journal.pone.0027108

Negro, R.W., C. Micheletto, R. Tosatto, M. Dionisi and P. Turco et al., 2007. Costs of asthma in Italy: Results of the Social Impact of Respiratory Integrated Outcomes (SIRIO) study. Respir. Med., 101: 2511-2519. DOI: $10.1016 /$ j.rmed.2007.07.011

Pakhale, S., A. Sumer, D. Coyle, K. Vandemheen and S. Aaron et al., 2011. (Correcting) misdiagnoses of asthma: A cost effectiveness analysis. BMC Pulm. Med., 11: 27-36. DOI: 10.1186/1471-2466-11-27
Pasquale, M.K., S.X. Sun, F. Song, H.J. Hartnett and S.A. Stemkowski, 2012. Impact of exacerbations on health care cost and resource utilization in chronic obstructive pulmonary disease patients with chronic bronchitis from a predominantly Medicare population. Int. J. COPD 7: 757-764. DOI: $10.2147 /$ COPD.S36997

Patel, S., J. Henderson and M. Jeffreys, 2012. Associations between socioeconomic position and asthma: Findings from a historical cohort. Eur. J. Epidemiol., 27: 623-631.

DOI: $10.1007 / \mathrm{s} 10654-012-9703-9$

Petru, V., 2008. Co víme o dětském astmatu? Pediatr. pro Praxi, 4: 186-191.

Pittman, T.P., C.I.J. Nykiforuk and J. Mignone, 2012. The association between community stressors and asthma prevalence of school children in Winnipeg, Canada. Int. J. Environ. Res. Public Health, 9: 579-595. DOI: 10.3390/ijerph9020579

Pohunek, P., A. Slámová and J. Zvárová, 1999. Prevalence průduškového astmatu, ekzémuaalergickérýmy u školníchdětí v Českérepublice. Čs. Pediat., 54: 60-68.

Pohunek, P. and A. Slámová, 1999. Prevalence průduškového astmatu a dalšíchalergickýchprojevů u školníchdětí v Českérepublice. Alergie, 1: 19-21.

Pringle, A., 2013. Asthma and the diversity of fungal spores in air. PLOS Pathogens, 9: e1003371- e1003371. DOI: 10.1371/journal.ppat.1003371.

Rodriguez, A., M. Vaca, G. Oviedo, S. Erazo and M.E. Chico et al., 2011. Urbanisation is associated with prevalence of childhood asthma in diverse, small rural communities in Ecuador. Thorax, 66: 1043-1050. DOI: 10.1136/thoraxjnl-2011-200225

Sadatsafavi, M., L. Lynd, C. Marra, B. Carleton and W.C. Tan et al., 2010. Direct health care costs associated with asthma in British Columbia. Can. Respir. J., 17: 74-80. DOI: 10.1155/2010/361071

Sadatsafavi, M., W. Chen and H. Tavakoli, 2016. Saving in medical costs by achieving guideline-based asthma symptom control: A population-based study. Allergy, 71: 371-377. DOI: 10.1111/all.12803

Song, W.J., E.J. Jo, J.W. Lee, S.H. Cho and K.U. Min et al., 2013. Staphylococcal enterotoxin specific IgE and asthma: A systematic review and meta-analysis. Asia Pac. Allergy, 3: 120-126. DOI: 10.5415/apallergy.2013.3.2.120

Stoner, A.M., S.E. Anderson and T.J. Buckley, 2013. Ambient air toxics and asthma prevalence among a representative sample of us kindergarten-age children. Plos ONE, 8: e75176-e75176.

DOI: $10.1371 /$ journal.pone.0075176

Subbarao, P., P.J. Mandhane and M.R. Sears, 2009. Asthma: Epidemiology, etiology and risk factors. CMAJ, 181: E181-E190. DOI: 10.1503/cmaj.080612 
Tan, H., C. Sarawate and J. Singer, 2009. Impact of asthma controller medications on clinical, economic and patient-reported outcomes. Mayo Clin. Proc., 84: 675-684. DOI: $10.4065 / 84.8 .675$

To, T., S. Stanojevic, G. Mores, A.S. Gershon and E.D. Bateman et al., 2012. Global asthma prevalence in adults: Findings from the cross-sectional world health survey. BMC Public Health. DOI: $10.1186 / 1471-2458-12-204$

To, T., S. Stanojevic, R. Feldman, R. Moineddin and E.G. Atenafu et al., 2013. Is asthma a vanishing disease? A study to forecast the burden of asthma in 2022. BMC Public Health. DOI: $10.1186 / 1471-2458-13-254$

Toru, U., C. Ayada, O. Genc, S. Sahin and Ö. Arık et al., 2015. Visfatin and ghrelin: Can they be forthcoming biomarkers or new drug targets for asthma? Int. J. Clin. Exp. Med., 28: 6257-6261. PMID: 26131235

Toskala, E. and D.W. Kennedy, 2015. Asthma risk factors. Int. Forum Allergy Rhinol., 5: S11-S16.

UZIS, 2013. Czech health statistics yearbook 2013. Ministry of Health, UZIS.

Weissflog, D., H. Matthys and J.C. Virchow, 2001. Epidemiology and costs of bronchial asthma and chronic bronchitis in Germany. Deutsche Medizin. Wochenschrift, 126: 803-810.

DOI: $10.1055 / \mathrm{s}-2001-15705$
Wong, G.W.K., T.F. Leung and F.W.S. Ko, 2013. Changing prevalence of allergic diseases in the asiapacific region. Allergy Asthma Immunol. Res., 5: 251-257. DOI: 10.4168/aair.2013.5.5.251

Zalewska, M., K. Furmanczyk, S.W. Jaworski, W. Niemiro and B. Samoliński, 2013. The prevalence of asthma and declared asthma in Poland on the basis of ECAP survey using correspondence analysis. Comput. Mathem. Meth. Med. DOI: $10.1155 / 2013 / 597845$.

Zehraeus, N., C.J. Petersson, M. Dozzi and A. Fiocchi, 2010. Health-care cost reduction resulting from primary-care allergy testing in children in Italy. Italian J. Pediat., 36: 1-7. DOI: 10.1186/1824-7288-36-61

Zhang, L., A., Xu, W. Zhao, Q.F. Xu and Y.M. Zhao et al., 2015. A Toll-Like Receptor 4 (TLR4) variant is associated with asthma severity. Int. J. Clin. Exp. Med., 8: 7849-7854. PMID: 26221339 